\title{
A rare Mid-Würmian lithoid tuff in the Agro Pontino graben (Southern Lazio, Italy) and its identification as an Albano 5-7 related distal tephra deposit (40-36 kaBP): characteristics, provenance and palaeogeographical implications
}

\author{
Jan Sevink ${ }^{1, *}$, Mauro A. Di Vito ${ }^{2}$, Monica Piochi $^{2}$, Angela Mormone ${ }^{2}$, Wouter van Gorp ${ }^{3}$, \\ Corrie C. Bakels ${ }^{4}$ \\ ${ }^{1}$ Institute for Biodiversity and Ecosystem Dynamics (IBED), University of Amsterdam, Amsterdam, The Netherlands \\ ${ }^{2}$ Istituto Nazionale di Geofisica e Vulcanologia (INGV), Osservatorio Vesuviano, Napoli, Italy \\ ${ }^{3}$ Groningen Institute of Archaeology, University of Groningen, Groningen, The Netherlands \\ ${ }^{4}$ Faculty of Archaeology, University of Leiden, Leiden, The Netherlands
}

Article history

Received August 31, 2017; accepted January 22, 2018.

Subject classification:

Geochronology; Stratigraphy; Volcanic rocks.

\begin{abstract}
A lithoid tuff, found in 2011 (Ricci pit, Agro Pontino, Southern Lazio, Italy), was studied for its composition, origin and palaeogeographical implications. This tuff was the first occurrence of a Würmian-age tephra layer, encountered in the coastal basins of Southern Lazio. Based on its mineralogy and isotopic composition (Sr and Nd), its stratigraphic position and the pre-and post-depositional soil formation and weathering, it was identified as a distal tephra deposit from the Colli Albani volcano, connected with the Albano 5-7 eruptive stage and dating from 40-36 ka BP. The lithoid tuff consists of tephra that were slightly reworked and subsequently lithified, when this central part of the Agro Pontino graben still consisted of a non-dissected, level lagoonal plain. The study confirms the earlier established importance of this tephra layer as stratigraphic marker for Central Italy, and shows that its distribution is wider than earlier assumed, notably to the SE of the Colli Albani volcano.

\section{Introduction}

In southern Lazio, Mid-Pleistocene tephra from the Colli Albani volcano (also described as the Volcano Laziale) and local eruption centres (Ernici) abound in its coastal plains (Agro Pontino, Fondi Basin) and mountains (Monti Lepini and Aurunci), while further to the southeast (Monti Ausoni and coastal area of Formia-Minturno) tephra from the Roccamonfina are common. Truly distal Würmian tephra from the Colli
\end{abstract}

Albani volcano, still active during that period in contrast to the Ernici (extinct) and Roccamonfina (very minor and local activity only), have not yet been reported for southern Lazio (Figure 1). Holocene tephra, discovered in the Agro Pontino and Fondi basin, originate from Campanian eruptions amongst which in particular the Avellino pumice eruption of the Vesuvius, but these are tephra layers of truly minor magnitude [a few centimetres only, Sevink et al. 2011, 2013].

To the south of Sezze, in the Ricci pit $\left(41^{\circ} 27^{\prime} 43^{\prime \prime} \mathrm{N}\right.$, $13^{\circ} 2^{\prime} 17^{\prime \prime} \mathrm{E}$ ) in the central part of the Agro Pontino (see Figure 2), we discovered a fairly thick (at least $40 \mathrm{~cm}$ ) layer of lithoid tuff of Late Pleistocene age [Bakels et al. 2015] that represents the first tephra layer of such age and nature ever discovered in this part of southern Lazio. Because of its thickness and petrology, and the absence of significant soil formation and weathering in this tuff and overlying sediments, the tuff would probably originate from one of the latest eruptions of the Colli Albani and might be linked to the Mid-Würmian Peperino Albano eruptive cycle [Freda et al. 2006], more recently described as the Albano 5-7 tephra by Giaccio et al. [2013, 2017b].

The overall geological setting of the Ricci pit within the graben, already known from the earlier study by Sevink et al. [1984], was further detailed by 


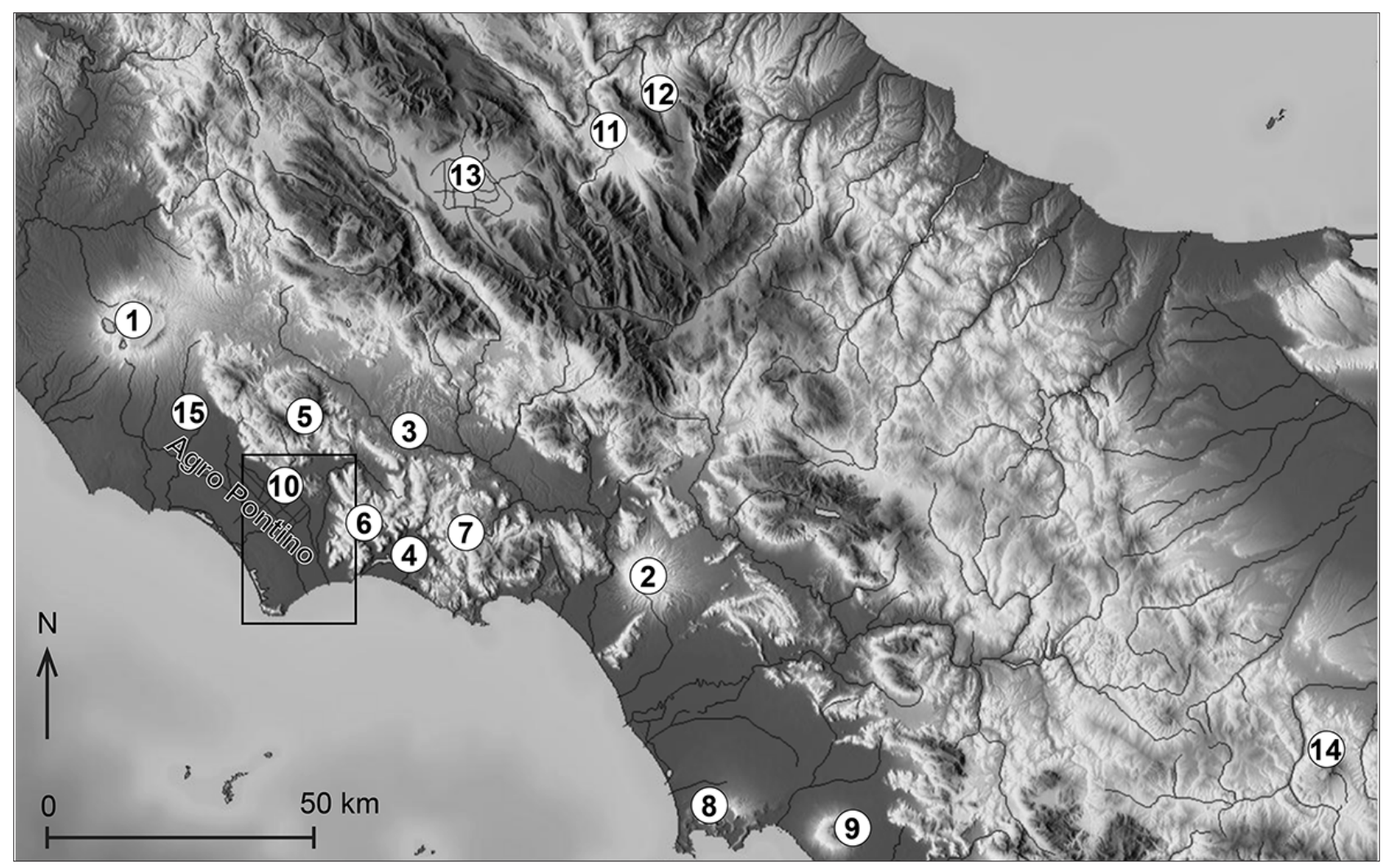

Figure 1. Central Italy and the Agro Pontino. 1. Alban Hills (Volcano Laziale); 2. Roccamonfina; 3. Ernici; 4. Fondi Basin; 5. Monti Lepini; 6. Monti Ausoni; 7. Monti Aurunci; 8. Campi Flegrei; 9. Vesuvius. Reported occurrences of Albano 5-7 distal tephra: 10. Ricci; 11. Sulmona; 12. Tirino; 13. Fucino; 14. Laghi di Monticchio; 15. Cisterna di Latina.

an extensive series of hand corings, executed in 20152017. Full results will be published in another paper [van Gorp and Sevink 2018], but relevant information on the Würmian dissection and drainage of the interior basin is presented here. This paper focuses on the characteristics and origin of this lithoid tuff, and the palaeogeographical implications of its occurrence.

\section{Background information}

\subsection{Regional setting}

Late Eemian/Early Würmian marine to lagoonal deposits, which were described as the Borgo Ermada complex [Sevink et al. 1984] and date from the MIS 5a stage [c. 80 ka BP: Hearty and Dai Pra, 1986, Schelmann et al. 2004, Asioli et al. 2005], are widely exposed in the south-eastern half of the Agro Pontino graben (Figure 2). Elsewhere in the graben, this complex is largely covered by Holocene deposits, which comprise peats and lacustrine to lagoonal deposits of the Terracina complex, and reddish-brown clays to clay loams with coarse textured gravel lenses and channel fills, together described as colluvio-alluvial to alluvial fan deposits [Sevink et al. 1984]. Over large areas, this Terracina complex holds a thin volcanic ash layer, attributed to the Avellino pumice eruption and dated at 1995 + / 10 calBC [Sevink et al. 2011]. The associated colluvio-alluvial to alluvial fan deposits hold Iron Age or later archaeological materials [e.g. Sevink et al. 1984, Feiken 2014], and are high in reworked pyroclastic material.

Going inland from the Borgo Ermada beach ridge, which is well preserved in the SE near Terracina (see Figure 2), the paleosurface of the Borgo Ermada complex is first marked by deep fluvial incisions by the PaleoAmaseno River and its tributaries, formed by backward incision at low sea level during the Würmian (see Figure 2). Upstream, to the NW, it changes into a slightly undulating, non-dissected lagoonal plain, which over large tracts is exposed or covered by only a thin veneer of Holocene deposits. This interior part drains through a single incision, cut into the Borgo Ermada complex near La Cotarda (see Figure 2). Extensive coring in the context of the soil survey by Sevink et al. [1984] showed that in this interior part the top of the Borgo Ermada complex exhibits a well-developed Vertisol in blueish heavy clay, in many places with a distinct and thick (up to $1 \mathrm{~m}$ ) petrocalcic horizon within 1 meter from the paleosurface. This horizon very regularly contains well-preserved Cardium shells, testifying to the lagoonal origin of the clays. The top of the Vertisol often holds some silt to sand-size volcanic material, but associated recognizable tephra layers were never encountered. 


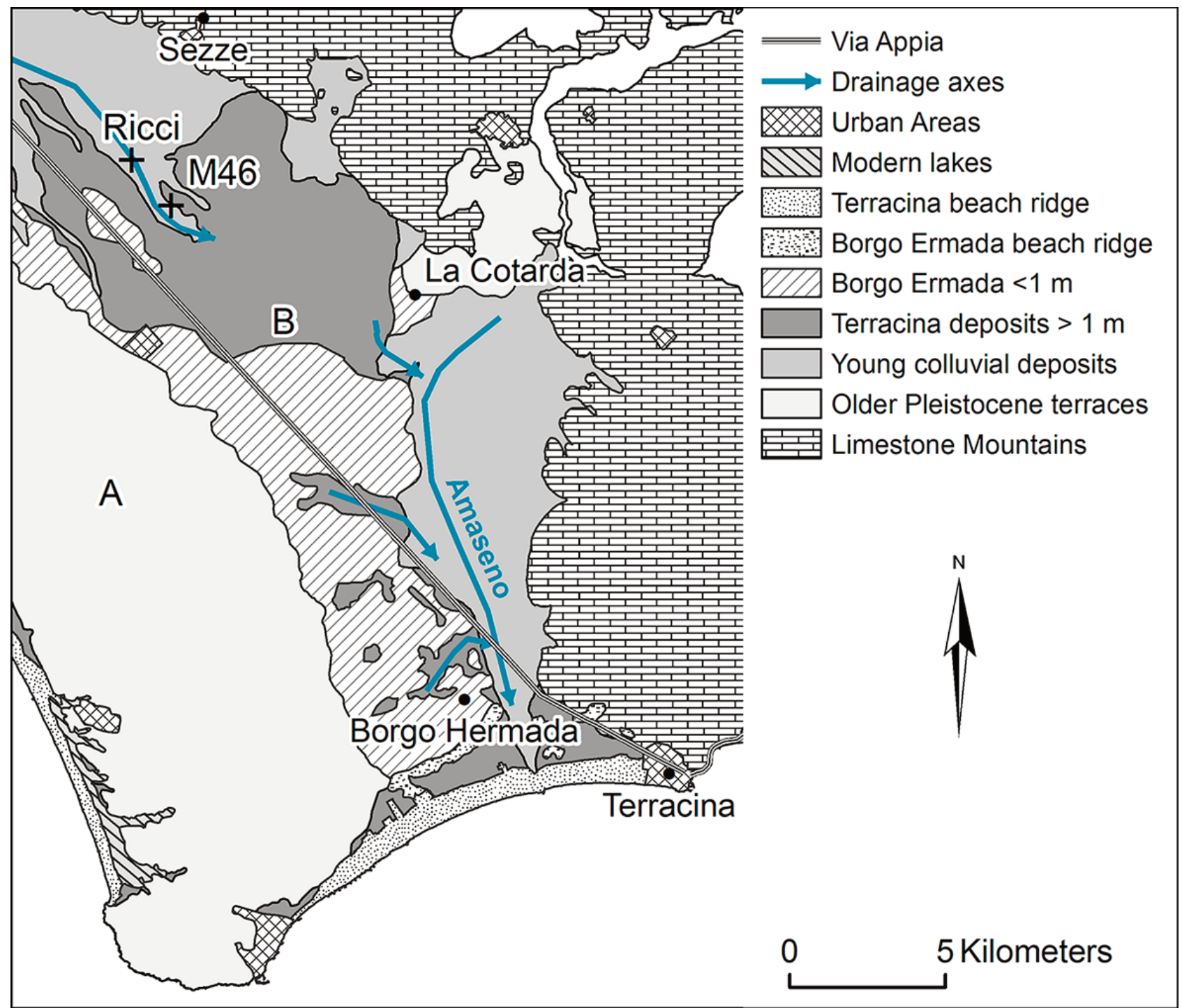

Figure 2. Location of the Ricci site and geology of the southern Agro Pontino (after soil map by Sevink et al. 1984). A = Higher complex of marine terraces; $\mathrm{B}=$ The Agro Pontino graben. Locations of Ricci and M46: +

In 2011, a large pit was dug in the plain to the $S$ of Sezze (Figure 2). In this Ricci pit, named as such after the land owner, underneath a colluvio-alluvial stratum a Holocene lacustrine complex with intercalated Avellino pumice layer (AV) was found, resting on a horizontal layer of dense, grey, fine grained lithoid tuff [Bakels et al. 2015]. This lithoid tuff in its turn was underlain by non-exposed lagoonal deposits of the Borgo Ermada complex, known from a large pit slightly further to the SE near the Via Migliara 46. In that pit, indicated as M46 in Figure 2, the lithoid tuff did not occur, but both the Vertic paleosol in the top of the clayey Borgo Ermada deposits and the associated petrocalcic horizon were very well developed.

\subsection{Relevant Late Pleistocene volcanic eruptions}

Relevant eruptions include the late eruptive cycles from the Colli Albani volcano [Freda et al. 2006, Giaccio et al 2007, 2013, 2017b], and from the Campi Fle- grei, in the form of the Campanian Ignimbrite [about 39.2 kaBP, De Vivo et al. 2001 and references therein, $39.85 \pm 0.14 \mathrm{kaBP}$, Giaccio et al. 2017a] and the Neapolitan Yellow Tuff [about 14.9 kaBP, Deino et al. 2004 and references therein]. Tephra from these various eruptions can be identified on the basis of their low $\mathrm{K}$ content and associated mineral chemistry [e.g., Piochi et al. 2004], and isotope geochemistry, in particular their ${ }^{87} \mathrm{Sr} /{ }^{86}$ ratio, which is higher for the products from the Colli Albani volcano [Freda et al. 2006, Giaccio et al. 2007, Gaeta et al. 2011, Giaccio et al. 2013], and their ${ }^{143} \mathrm{Nd} /{ }^{144}$ ratio, which is slightly lower for the Campi Flegrei products [Pappalardo et al. 2002, Arienzo et al. 2010, Di Renzo et al. 2011, Piochi et al. 2014].

Giaccio et al. [2013] published an overview of the distribution, age, and isotopic (coupled Sr-Nd) and major element fingerprinting of the distal tephra of the Colli Albani volcano. They extensively report on the occurrence of Late Quaternary Colli Albani tephra 


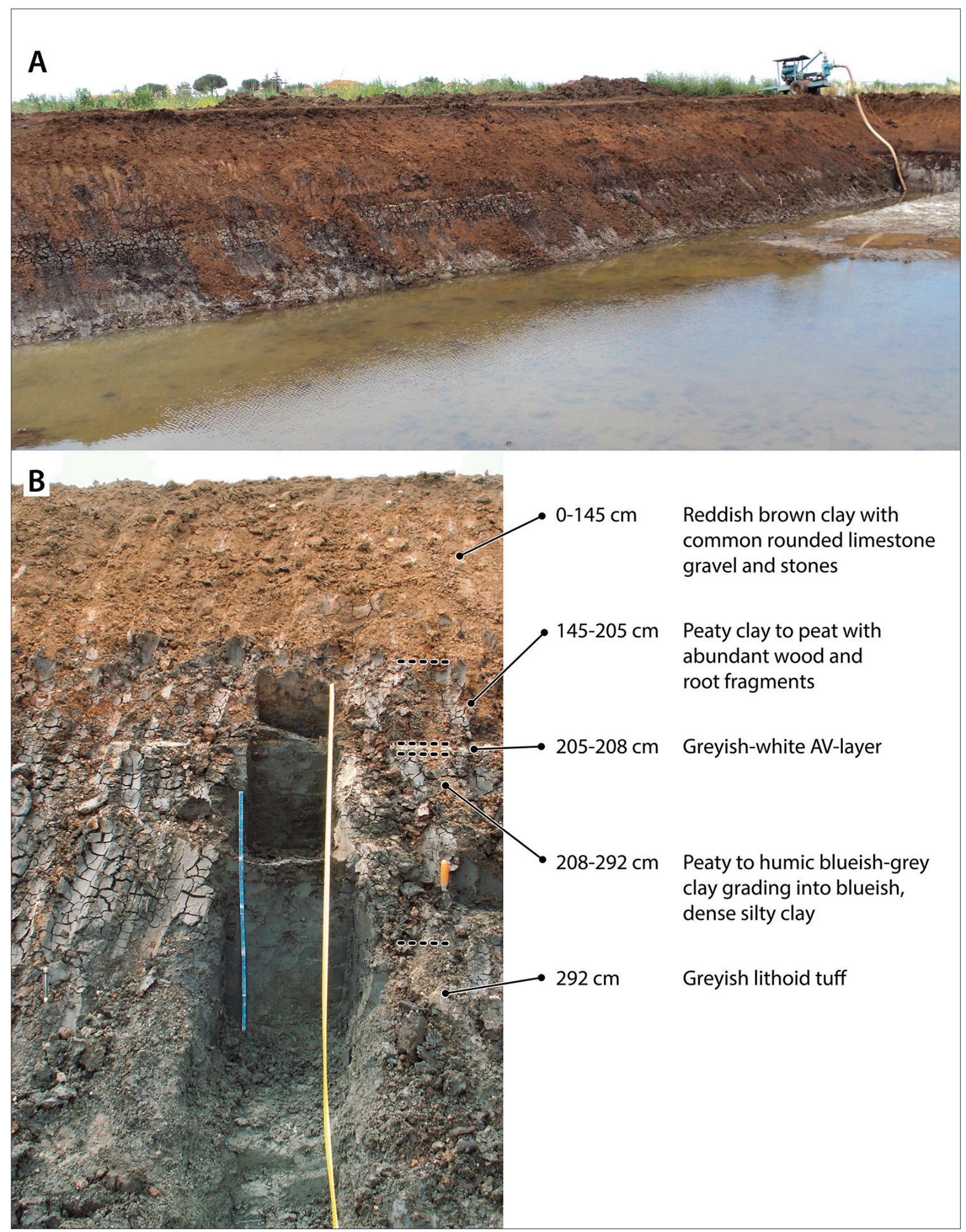

Figure 3. The Ricci pit (A) and section (B; with description). Sample is from c. $300 \mathrm{~cm}$ in greyish lithoid tuff.

in tectonic basins in the Apennines, such as that of Sulmona, Tirino and Fucino (see Figure 1), whereas for the Tyrrhenian coastal basins such tephra were not reported. They refer to these most recent Colli Albani tephra [Freda et al. 2006] as the Albano 5-7 units and state that these distal tephra are important tephrostratigraphic marker beds. Freda et al. [2006] refer to the younger second cycle eruptions of units 5-7 (c. 39 
$\mathrm{kaBP}$ ) as being more violent than the older eruptions (units 1-4). In the most recent publication by Giaccio et al. [2017b], the Albano 5 and 7 are reported as the most energetic explosive episodes during the late stage, dating from $\sim 40$ and $\sim 36 \mathrm{kaBP}$, respectively.

Gatta et al. [2017] very recently published a tentative study based on a preliminary data set of trace element compositions of whole rock samples from the various Albano units. They suggested that such analysis may eventually become useful to distinguish between the various units and be applied, if other methods are impracticable because of the absence of suited glass or fresh primary minerals, needed for conventional major element fingerprinting and Ar dating (e.g. unaltered sanidine).

\section{Methods}

In the Ricci pit, the exposed sedimentary sequence was described and sampled (see Figure 3 ). The lithoid tuff formed the basis and was at least about 40 $\mathrm{cm}$ thick judging from the size of the largest blocks encountered on the inundated floor of the pit. These blocks resulted from breaking up the tuff during the excavation of the pit and were sampled for further study. Thin sections were prepared from one of the blocks. Another block was fragmented and fragments gently ground to pass a $2 \mathrm{~mm}$ mesh sieve. The sieve fraction was pre-treated with $\mathrm{H}_{2} \mathrm{O}_{2}$ and $\mathrm{NaOH}$, followed by wet sieving over a $63 \mu \mathrm{m}$ sieve. The fraction $<$ $16 \mu \mathrm{m}$ was separated by repeated sedimentation and siphoning till the suspension was clear, followed by centrifugation of the suspensions obtained. Sand fractions were obtained by dry sieving of the residue from the $63 \mu \mathrm{m}$ sieve.

Radiocarbon dating was carried out at the Centre for Isotope Research at Groningen University, The Netherlands, on a tuff block, fragmented and ground to pass a $2 \mathrm{~mm}$ mesh sieve. The sieve fraction was chemically pre-treated to remove carbonates and organic contaminants [ABA extraction, Mook and Streurman 1983], and subsequently combusted to release $\mathrm{CO}_{2}$, which was analyzed by AMS. The conventional dating obtained was calibrated using the OxCal v4.2.4 program [Bronk Ramsey 2013] and the IntCal13 atmospheric curve [Reimer et al. 2013].

Chemical and mineralogical analyses were performed at the Istituto Nazionale di Geofisica e Vulcanologia, Osservatorio Vesuviano (Naples, Italy).

A preliminary mineralogical analysis of the tuff was performed by conventional optical microscopy on loose material and a thin section. This was followed by more detailed diffraction and electron microscopy.
Diffraction data were obtained by an X'Pert Powder diffractometer (PANalytical), equipped with a high speed PIXcel detector, a Ni-filter or a diffracted-beam monochromator, and $\mathrm{CuK} \alpha$ radiation, at $40 \mathrm{kV}$ and 40 $\mathrm{mA}$ in a $3-70 \mathrm{o} 2 \theta$ range, with $0.02^{\circ}$ steps at $8 \mathrm{~s} / \mathrm{step}$. Samples analyzed included selected grains, minerals and whole rocks, previously powdered in an agate mill. Diffraction patterns were elaborated and interpreted using the X'Pert HIGH Score Plus computer program.

Mineralogical studies of useful tuff components and their elemental composition (major elements, EDS) were performed using a Field Emission Scanning Electron Microscope SIGMA from ZEISS equipped with a X-Max ${ }^{\mathrm{N}}$ micro-analysis system by Oxford, controlled by SMARTSEM and AZTEC software. The most useful component (micas, as explained in the discussion) was handpicked under the binocular microscope and mounted on a stub specimen, graphitized by a QUORUM instrument. The analytical conditions include: InLens, SE2 and BSE detectors, $15 \mathrm{kV}$ accelerating voltage, and a working distance of $8.5 \mathrm{~mm}$. Qualitative spectra were obtained after Co calibration.

Strontium $(\mathrm{Sr})$ and neodymium $(\mathrm{Nd})$ isotope compositions were determined in duplicate on micas by thermal Ionization Mass Spectrometry (TIMS), using a ThermoFinnigan Triton TI multicollector mass spectrometer. Mineral samples of $0.2 \mathrm{~g}$, handpicked under a binocular to select grains with non-corroded margins, were washed several times, then rinsed in pure $\mathrm{H}_{2} \mathrm{O}$ Milli Q ${ }^{\circledR}$. After a preliminary $2.5 \mathrm{~N} \mathrm{HCl}$ leaching for $10^{\prime}$ and dissolution by HF-HNO3-HCl, $\mathrm{Sr}$ and $\mathrm{Nd}$ were separated by conventional ion-exchange chromatographic techniques. The Sr blank was in the order of $0.1 \mathrm{ng}$ during the period of chemical processing. Measured ${ }^{87} \mathrm{Sr} /{ }^{86} \mathrm{Sr}$ and ${ }^{143} \mathrm{Nd} /{ }^{144} \mathrm{Nd}$ isotope ratios were normalized for within-run isotopic fractionation to ${ }^{86} \mathrm{Sr} /{ }^{88} \mathrm{Sr}=0.1194$ and ${ }^{146} \mathrm{Nd} /{ }^{144} \mathrm{Nd}=0.7219$, respectively. The external reproducibility $2 \sigma$ is calculated according to Goldstein et al. [2003]. Sr and Nd isotope ratios have been normalized to the recommended values of NIST SRM $987\left({ }^{87} \mathrm{Sr} /{ }^{86} \mathrm{Sr}=0.71025\right)$ and La Jolla $\left({ }^{143} \mathrm{Nd} /{ }^{144} \mathrm{Nd}=0.51185\right)$ standards, respectively.

\section{Results and discussion}

4.1 The Ricci pit: general characteristics of the section and lithoid tuff

Figure 3 shows a characteristic section of the Ricci pit, with a concise description of its stratigraphy. The lithoid tuff appeared as a homogenous fine-grained, weakly stratified and dense, hard tuff. Stratification can be described as wavy parallel, with abundant mica on 

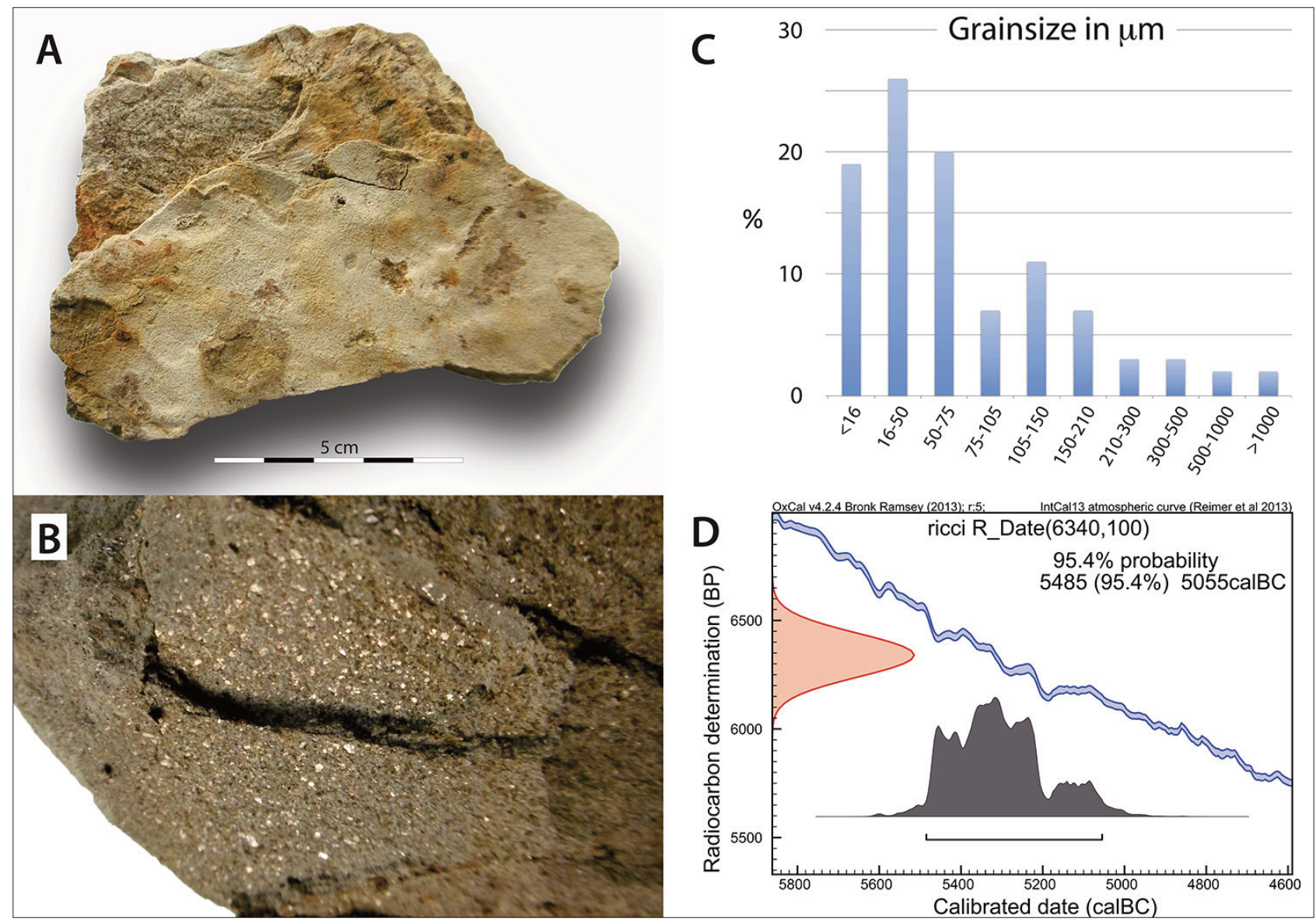

Figure 4. a) Lithoid tuff fragment showing the wavy parallel bedding and former rooting; b) Abundant mica on surface of bed; c) Grain size distribution; d) Radiocarbon age (in cal BC).

planes (see Figures $4 \mathrm{a}$ and $4 \mathrm{~b}$ ). More or less peaty lacustrine clays with intercalated AV-layer, and reddish brown clays cover it, respectively. The grain size of the tuff was typically slightly bimodal fine sandy loam to loam with a significant silt/clay content (see Figure 4c), but this analysis should be considered as tentative since full dispersion into primary particles could not be achieved because of its cementation. Its lithoid character and granulometry (fine-grained and bimodal) are also evident in the thin section (see Figure 5). Figure 5 also demonstrates the compactness of the tuff and its distinct stratification, and evidences the presence of some fossils (Figures $5 \mathrm{~b}$ and $\mathrm{d}$ ).

The upper part of the tuff layer (approx. $10 \mathrm{~cm}$ ) was weathered and, overall, had lost its lithoid character, but still contained some hard tuff fragments. Its transition towards the overlying more or less calcareous humic blueish clay was distinct. The weathering evidences a hiatus of ill definable length, clearly with terrestrial conditions, between the tuff and overlying clay. However, soil formation and weathering were of minor magnitude, considering the limited thickness of the weathered zone, absence of vertic properties, and virtual absence of calcium carbonate redistribution.
An indication for the age of the onset of the lacustrine conditions and a terminus ante quem for the emplacement of the lithoid tuff can be found in the ${ }^{14} \mathrm{C}$ age of the organic material extracted from the lithoid tuff: the ${ }^{14} \mathrm{C}$ dating of the organic matter contained in a block of lithoid tuff gave an age of 50555485 calBC (see Figure $4 d$ ). As to the origin of this organic matter, root channels filled with dark colored fine plasma and plant remains were macroscopically visible in the tuff blocks and were also observed in the thin section. Furthermore, in the immediately overlying more or less peaty lacustrine sediment, fragments of tree trunks, branches, and roots are common.

Around 5000 BC sea level was still at $-10 \mathrm{~m}$ asl or even lower [Lambeck et al. 2004, 2011; Parlagreco et al. 2011] and the river that drained the graben had not yet been blocked by the built-up of a fan by the Amaseno river as a result of sea level rise [Van Gorp and Sevink 2018]. It was this fan that induced the development of the inland lake and associated deposits, such as those found in the Ricci pit. This leads to the conclusion that the organic matter for which the $14 \mathrm{C}$ age was obtained originates from roots of the vegetation, present prior to the development of the lacustrine 


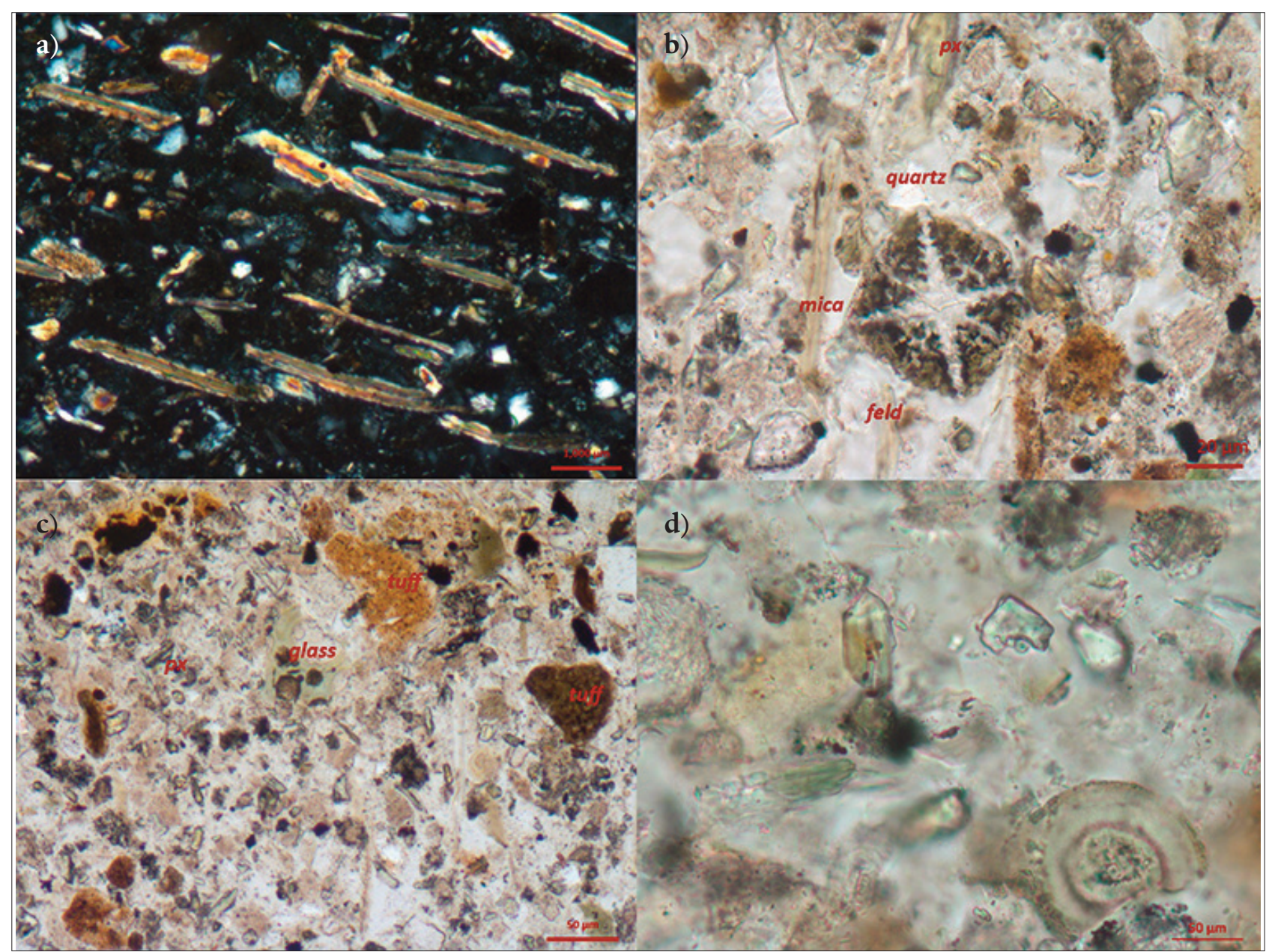

Figure 5. Thin section: a) Parallel bedded mica (biotite and phlogopite) under cross polarized light; b) Ricci tuff texture with fossil and various minerals under polarized light; c) Ricci tuff components. Note the tuff grains and vesicular glass shards under polarized light; d) Oolitic nodule under polarized light.

conditions and penetrating into the underlying lithoid tuff. This date also provides a terminus ante quem for the emplacement of the tephra.

\subsection{Composition and provenance of the tuff}

From the general observations and discussion in 4.1 (further elaborated in 4.3 for its palaeogeographical implications), it is evident that the lithoid tuff is encountered in a very specific context, which constrains its provenance and age: a) the tuff was emplaced on top of the lagoonal deposits of the Borgo Ermada level (of Late Eemian/Early Würmian age, c. $80 \mathrm{ka} \mathrm{BP),} \mathrm{but} \mathrm{also}$ after the development of a (post-depositional) prominent paleosol and associated petrocalcic horizon in these lagoonal clays, and b) at least some time before $c$. $5000 \mathrm{BC}$. The foregoing implies that in the discussion we can focus on eruptions/volcanic origins that within the above time constraints were relevant and thus exclude volcanoes such as the Ernici and Roccamonfina.

Macroscopically, the lithoid tuff appears as a rather dense, stratified lithoid tuff with common zeolites and some macrospores (root channels). In thin section, it is a low-cohesive, strongly altered ash, composed of fine matrix material of which the mineral composition can not be established optically, and of a large variety of crystals, minor abundance of tuff clasts, and very rare glass shards. Glass fragments, with their conchoidal fracture and vesicles, are greenish (see Figure 5c). Tuff grains are brownish, most probably because of oxidation, and may contain some minute feldspar and magnetite fragments. Calcite and zeolite occur in voids and fractures. The tuff is locally glauconized, contains some microfossils composed of calcium carbonate/silicate skeletons (Figure $5 \mathrm{~b}$ ), and holds some greenish and whitish ooid structures (see Figure $5 \mathrm{~d}$ ).

Crystals commonly occur as well-sorted isolated grains with a median size of up $100 \mu \mathrm{m}$ and comprise quartz, mica, pyroxene, apatite, spinel, and rare feldspar and zircon. Quartz and most of the pale green pyroxene grains occur as more or less angular crystal fragments, but smaller pyroxenes may have a sub-euhedral habit. Among the crystals, mica dominates (ca. $20-30 \%$ by area), reaching far larger dimensions than 


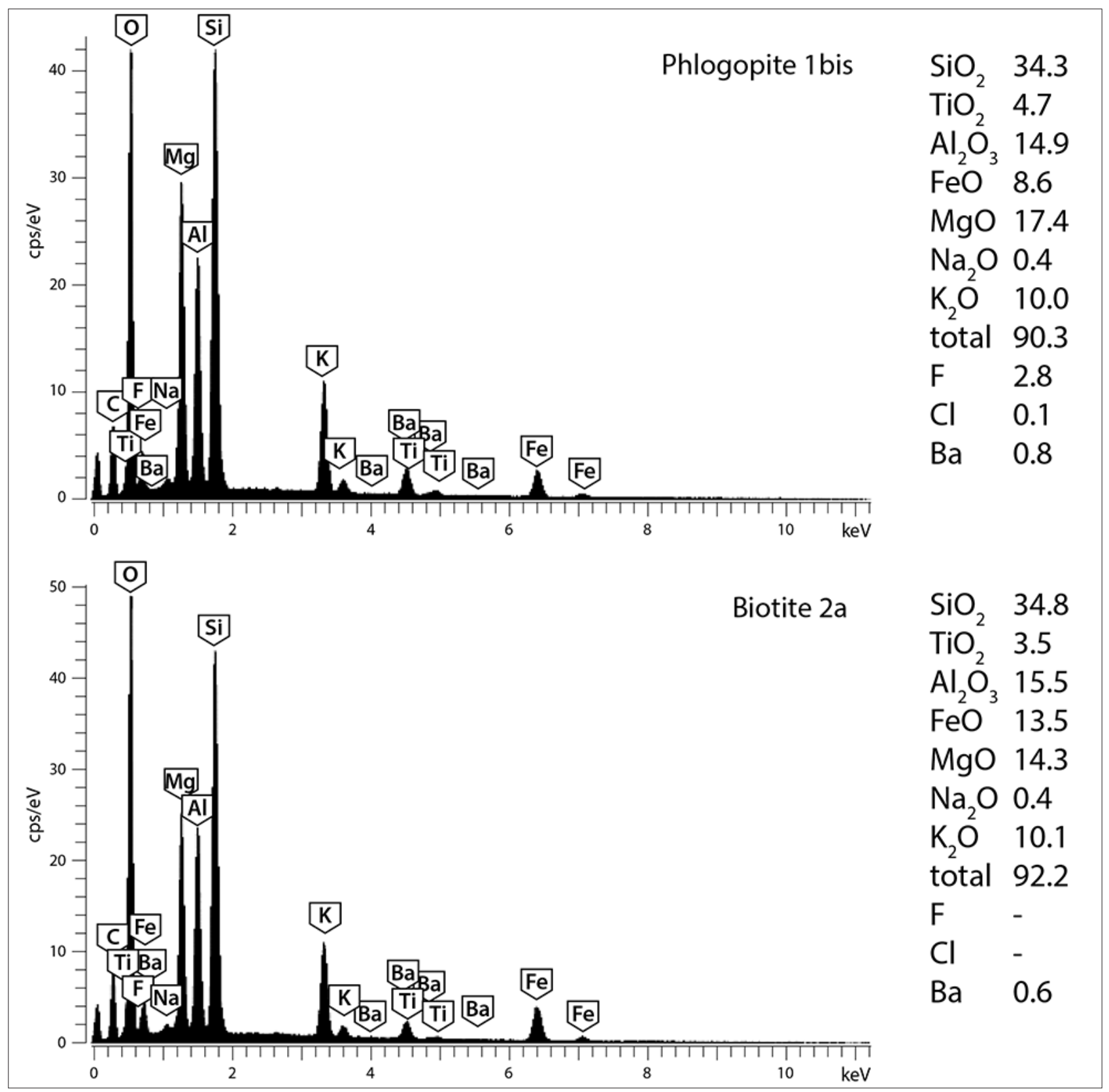

Figure 6. Chemical data on mica from the Ricci lithoid tuff: phlogopite and biotite.

the other crystals and exhibiting a distinctly parallel orientation (see Figure 5a). The optical properties of the mica crystals suggest that phlogopites dominate, with crystals ranging from rather fresh to iridescent due to chloritisation, whereas some are surrounded by cubic white crystallites.

The XRD powder spectra for the whole rock support the optical information and point to the presence of mica, albite, diopside and leucite/analcime, without appreciable amorphous glass phases. In the lithoid tuff, volcanic glass fragments also appear to be strongly weathered (see also fig 5). Therefore, we considered that phase to be unsuited for reliable and statistically consistent analysis of its original chemical composition. The micas instead offered a good possibility by both chem- istry and coupled $\mathrm{Nd}$ and $\mathrm{Sr}$ isotope geochemistry to discriminate between the Campanian vs. Latium volcanism. This possibility was stressed in the most recent literature, stating that isotope geochemistry is a good discriminant for the identification of Colli Albani tephra [Gaeta et al. 2011, Giaccio et al. 2013].

The XRD spectra from handpicked mica show that mainly phlogopite and subordinate biotite are present, whereas powder spectra for the whole rock point to the additional presence of albite, diopside and additional analcime. Moreover, EDS spot observations confirmed the coexistence of both phlogopite and biotite [e.g., Balassone et al. 2014], which differ for their Fe and Ti contents that are, respectively, lower and higher than $10 \%$ and $2 \%$, and for the presence of $\mathrm{F}$ in the phl- 


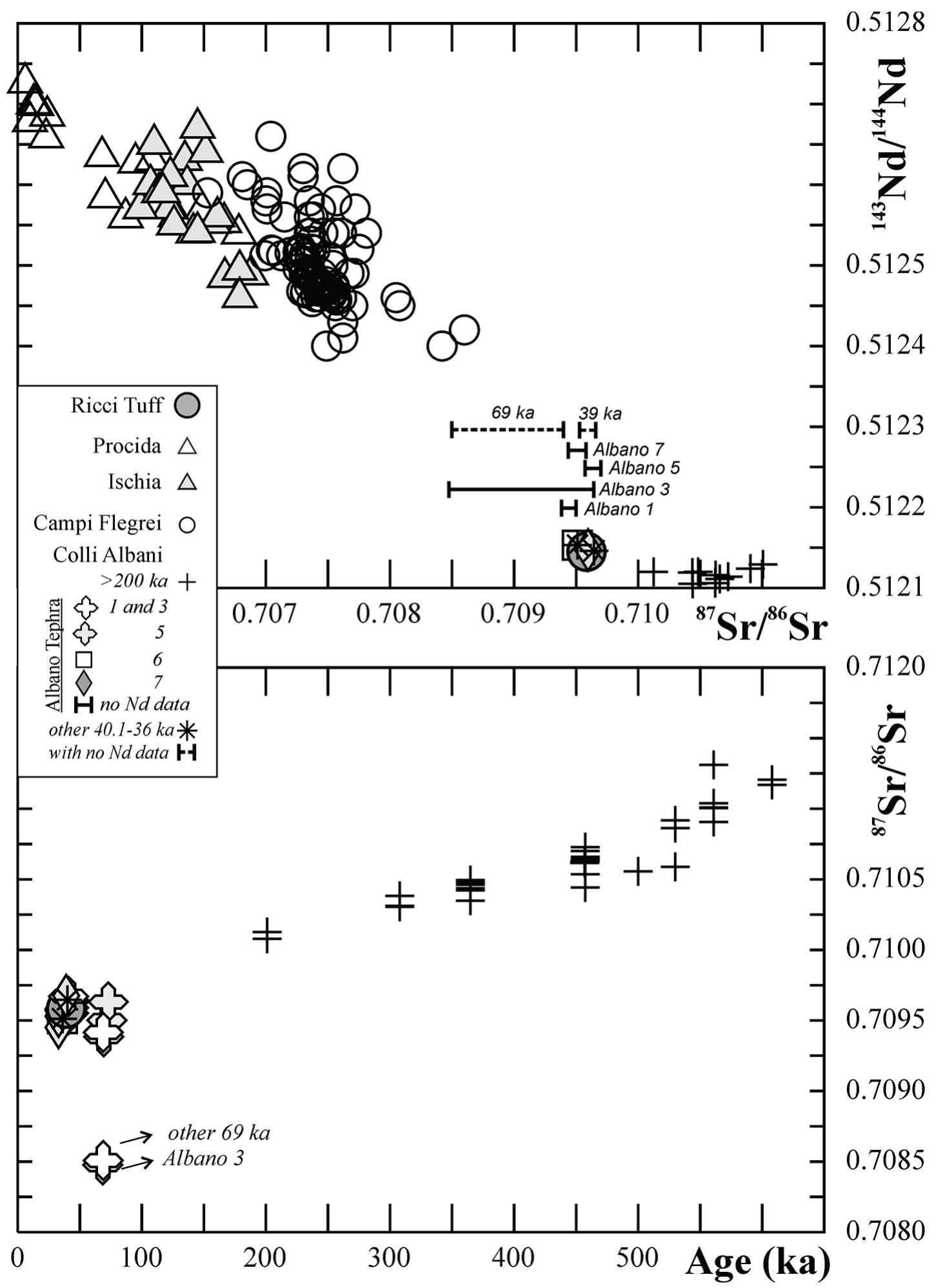

Figure 7. Isotopic compositions of relevant tephra (Colli Albani, Campi Flegrei, Procida and Ischia) and lava (Colli Albani). A: Sr and Nd isotopic ratios. For samples from the various Albano phases with unknown Nd isotopic ratio ('no Nd data') bars were used indicating the range in Sr isotopic ratio. Data from Freda et al. (2006), not linked to a specific phase but of known age, are indicated by bars with dashed lines. Data from Gaeta et al. (2011) on lava are indicated as 'other 40.1-36 ka'. B: Sr-isotopic ratios for the Colli Albani rocks over time. Note: For the Ricci biotite the assumed age is used. Data for Campi Flegrei, Procida, and Ischia: De Astis et al. (2004); D'Antonio et al. (1999); de Vita et al. (1999); Orsi et al. (1995); Pabst et al. (2008); Pappalardo et al. (1999; 2002); Piochi et al. (1999); Vezzoli (1988); data for Colli Albani: Bosi et al. (1991); Freda et al. (2006); Gaeta et al. (2006; 2011); Giaccio et al. (2007; 2013).

ogopite (see spectra in Figure 6). Thus, the phlogopite is richer in $\mathrm{Mg}$, relative to the biotite, and shows an $\mathrm{F}$ content of up to 2.32 weight $\%$. This F-rich phlogopite is also rich in $\mathrm{Ba}$ (up to $1.8 \%$ ). Overall, the mineral composition resembles that of the Albano 5-7 units as described by e.g. Freda et al. [2006] and Giaccio et al. 
[2013, 2017b]. However, it is not possible to exclude the Albano 1 and 3 units on the basis of these results. Lastly, the (rare) quartz and albite grains must originate from nearby Pleistocene sands (marine terraces, see Sevink et al. 1984), and their presence as well as that of the microfossils indicate that the tephra has been reworked before being lithified.

As to the chemical/isotopic composition, the TIMS analysis show that the phlogopites have an ${ }^{87} \mathrm{Sr} /{ }^{86}$ ratio of $0.709584 \pm 10$ and ${ }^{143} \mathrm{Nd} /{ }^{144} \mathrm{Nd}$ ratio of $0.512145 \pm 6$. Isotopic ratios of such phlogopites are typical for HK volcanic products, such as those from the Vesuvius and Latium Province (see Figure 7). They significantly differ from the ones from the Campanian Province, i.e. the Campanian Ignimbrite and Neapolitan Yellow Tuff, which contain biotite. Assuming that isotope equilibrium existed between clinopyroxenes and phlogopites, resulting from the contemporaneous crystallization of those mineral phases during a dominant magmatic fractionation process [Freda et al. 2006], the measured isotope ratios match with those reported for the $<69 \mathrm{kaBP}$ Colli Albano volcano [Freda et al. 2006, Giaccio et al. 2007, Gaeta et al. 2011, Giaccio et al. 2013]. In particular, the ${ }^{87} \mathrm{Sr} /{ }^{86}$ ratio of $0.709584 \pm 10$ (Figure 7) approaches the values of Albano 1 (0.709385-0.7095), falls in the Albano 3 range (0.708477-0.70963), and perfectly overlaps the values of Albano 5-7 (0.709512- 0.709675) [Freda et al. 2006, Giaccio et al. 2007, 2013, 2017b]. However, the Ricci tuff lacks olivine that instead is typically recovered in the Albano 1 (DU1 in Giaccio et al., 2007: when in distal position). Furthermore, phlogopite dominates the Ricci sample, but not the Albano 3 tephra [see Freda et al. 2006 and Giaccio et al. 2007], distal deposits from this phase being indicated as the DU2 tephra [Giaccio et al. 2007]. The ${ }^{143} \mathrm{Nd} /{ }^{144} \mathrm{Nd}$ of $0.512145 \pm 6$ also meets the known values for Albano 5-7 tephra (or DU3 and DU4), taking into consideration the magnitude of the errors. Moreover, the Nd-isotope ratios are slightly lower than those from volcanic products of Campanian Ignimbrite and Neapolitan Yellow Tuff [Pappalardo et al. 2002, Arienzo et al. 2010, Di Renzo et al. 2011, Piochi et al. 2004, 2014].

All together, the analyses show that the lithoid tuff originates from the Colli Albani volcano and may be a distal variant of the Albano 5-7 unit, more explicitly from the larger events during this eruptive phase: Albano 5 (DU3) or Albano 7 (DU4) from $\sim 40$ and $\sim 36$ kaBP, respectively [Giaccio et al. 2013, 2017b]. This would be in agreement with the statement by Gaeta et al. [2011] that Colli Albani tephra with an age younger than $69 \mathrm{ka}$ can be quite well discriminated from earlier tephra by their Sr-isotopic ratios. However, others found isotopic compositions of DU1, 2, 3, and 4 to be quite similar and we therefore have to conclude that our results do not allow for a decisive attribution to the youngest cycle on the basis of the Sr-isotopic ratios only. This is evidenced by Figure 7 in which an overview is given of all published data on tephra [Bosi et al. 1991, Freda et al. 2006, Gaeta et al. 2006, Giaccio et al. 2007, 2013, 2017; and lava [Gaeta et al. 2011] for the various eruptive phases. Lastly, in the recent literature hardly any data are presented on $\mathrm{Nd}$ isotope compositions of the Colli Albani phases 17 (DU1-4), the available data being limited to 4 values of which 2 for tephra [phase 6-proximal: Bosi et al. 1991, phase 7-distal: Giaccio et al. 2013]. The scarceness of data on $\mathrm{Nd}$ isotopic ratios prevents a more reliable identification.

\subsection{Palaeogeography}

For the central part of the graben, Sevink et al. [1984] already showed that the paleosurface of the Borgo Ermada complex consists of a rather level plain at an altitude of between 2 and $3 \mathrm{~m}$ asl, which drains to the SE through a single, narrow and deep incision immediately south of La Cotarda (see Figure 2). This was confirmed and further detailed by recent corings [Van Gorp and Sevink 2018]. The incision reaches down to at least about $5 \mathrm{~m}$ below current sea level and had been cut into clayey Borgo Ermada sediments that hold a prominent and resistant petrocalcic horizon with abundant Cardium shells within a meter from the paleosurface. Though not reached in the Ricci pit, evidence from a nearby site shows that these are also present below the lithoid tuff at Ricci. Furthermore, soil development in and weathering of the lithoid tuff is very limited. These observations can be interpreted in terms of a) indications for the age of the lithoid tuff, and $b$ ) the timing of the dissection and erosion of the Borgo Ermada lagoonal plain.

\subsubsection{Age of the lithoid tuff}

Considerable time must have elapsed after soil formation started in the Borgo Ermada surface at the end of MIS 5a [approx. $80 \mathrm{kaBP}$, see e.g. Schellmann et al. 2004 and references therein; Asioli et al. 2005] and before the lithoid tuff was deposited. Unfortunately, a more precise estimate of the period of time required for the formation of a pronounced petrocalcic horizon than 'at least several tenths of thousands of years' is impossible since such petrocalcics are relatively poor indicators [see e.g. Wright 1990, Candy et al. 2004, Alonso-Zarza and Tanner 2006]. Nevertheless, they re- 
quire a considerably longer period of time than the less than c. $10 \mathrm{ka}$, which would be available if the lithoid tuff dated from the early Albano eruptions that took place at c. $70 \mathrm{kaBP}$ (DU1 and DU2).

A similar line of reasoning can be followed for the length of the period that followed after its deposition, but before its burial underneath the lacustrine deposits. The limited soil formation and weathering at first sight might be considered as pointing to a truly short period only. Important is that the intensity of soil formation and weathering strongly depends on the climatic conditions, which particularly during the second half of the Würmian climate were mostly cool and dry, and not favorable for significant weathering and soil formation to occur, in contrast to the first half of that glacial period [see e.g. Cremaschi et al. 1990, Zucca et al. 2014, Gatta et al. 2016].

The limited impact on the lithoid tuff thus can be well explained by a combination of a shorter period ( $30 \mathrm{kaBP}$ ) and lesser intense soil formation and weathering, and in this light the situation observed is in decisively strong support of a deposition of the lithoid tuff at Ricci at 40-36 kaBP and its identification as Albano 57, and not Albano 3 (at c. $70 \mathrm{kaBP}$ ). In their study of the Cava Muracci, where they found an Albano 3 tephra layer, Gatta and Rolfo [2017] indeed observed pronounced soil formation and weathering in overlying strata (Layer SU 11: 45-100 cm highly consolidated redbrown clay soil; layer SU 12; very compact 20 -to- $40 \mathrm{~cm}$ thick layer of reddish-brown clay; on SU 13: tephra identified as Albano 3).

4.3.2 Dissection and erosion of the Borgo Ermada lagoonal plain

Evidently, the more precise timing of the incision and resulting slight dissection of the earlier formed lagoonal plain in the central part of the graben are hard to establish from the coring data. Nevertheless, some indication can be obtained when combining the various observations and data.

The fluvial incision near La Cotarda, cut into Borgo Ermada lagoonal clays which held a distinct petrocalcic horizon, is situated quite far inland (see Figure 2), and it is only later during the Würmian that a truly low sea level was reached: Around $40 \mathrm{kaBP}$ sea level stood fairly low (around -60 masl), to further descend later in the Würmian and reach a minimum of about -125 masl by the Last Glacial Maximum (LGM) that ended at ca. 19 kaBP [see e.g. Pillans et al. 1998, Clark et al. 2009]. The fluvial incision thus very likely dates from the Late Würmian, e.g. the LGM, implying that at the time of deposition of the lithoid tuff the inland Borgo Ermada surface was still largely non-dissected and indeed a distinct petrocalcic horizon had developed.

In Central Italy, during the Würmian glacial and from around $40 \mathrm{kaBP}$ onward, the forest cover was often seriously reduced and relatively dry herbaceous vegetation is assumed to have dominated [e.g. Follieri et al. 1998 and Gatta et al. 2016]. Under such conditions, with a very clayey and impermeable subsoil, even slight surface erosion may easily have led to largescale stripping of the Borgo Ermada paleosurface from freshly fallen tephra and its redeposition in the lowest parts of this plain, which include the Ricci area. Furthermore, contemporary soil conditions in those lowest parts can be described as saline and poorly drained, because of the overall dry climate and high salinity of the impermeable Vertisols, developed in the marine clays of the Borgo Ermada complex. The latter (high salinity) is still observable today [see Sevink et al. 1984]. Zeolitisation and the concurrent lithification of the (reworked) tephra are known to be promoted by such conditions [Langella et al. 2001], explaining the lithoid nature of the tuff at Ricci and its direct surroundings.

Such sequence of events and the variation in local conditions within the region well explain the absence of this lithoid tuff elsewhere in the Agro Pontino Graben and the frequent occurrence of a minor volcanic component in the top of the more or less truncated Vertisols in the more level central and southeastern parts of the graben.

\section{Conclusions}

Based on its $\mathrm{Sr}$ and $\mathrm{Nd}$ isotopic composition, on its general characteristics (texture, mineralogy and thickness), as well as on its stratigraphic position, and pre- and post-depositional soil formation and weathering, it is concluded that the lithoid tuff encountered at Ricci is of Mid-Würmian age and originates from the Albano 5 (DU3) or Albano 7 (DU4) eruptive episodes of the Colli Albani. These date from 40-36 kaBP [Giaccio et al. 2007, 2013, 2017b].

Identification of the lithoid tuff on the basis of only the available chemical and mineralogical data is rather hampered by the broad similarity in composition of the products from the several Albano eruptive cycles, but the data perfectly match with the known composition of the Albano 5-7 tephra. Alternative geochemical methods, such as trace-element fingerprinting of bulk rock [Gatta et al. 2017], are problematic because of the presence of allochtonic material (e.g. quartz, albite, and pyroxene) and of its rather prominent zeolitisation, with a concurrent strong alteration of volcanic glass. Sanidine is rare, if present at all, ham- 


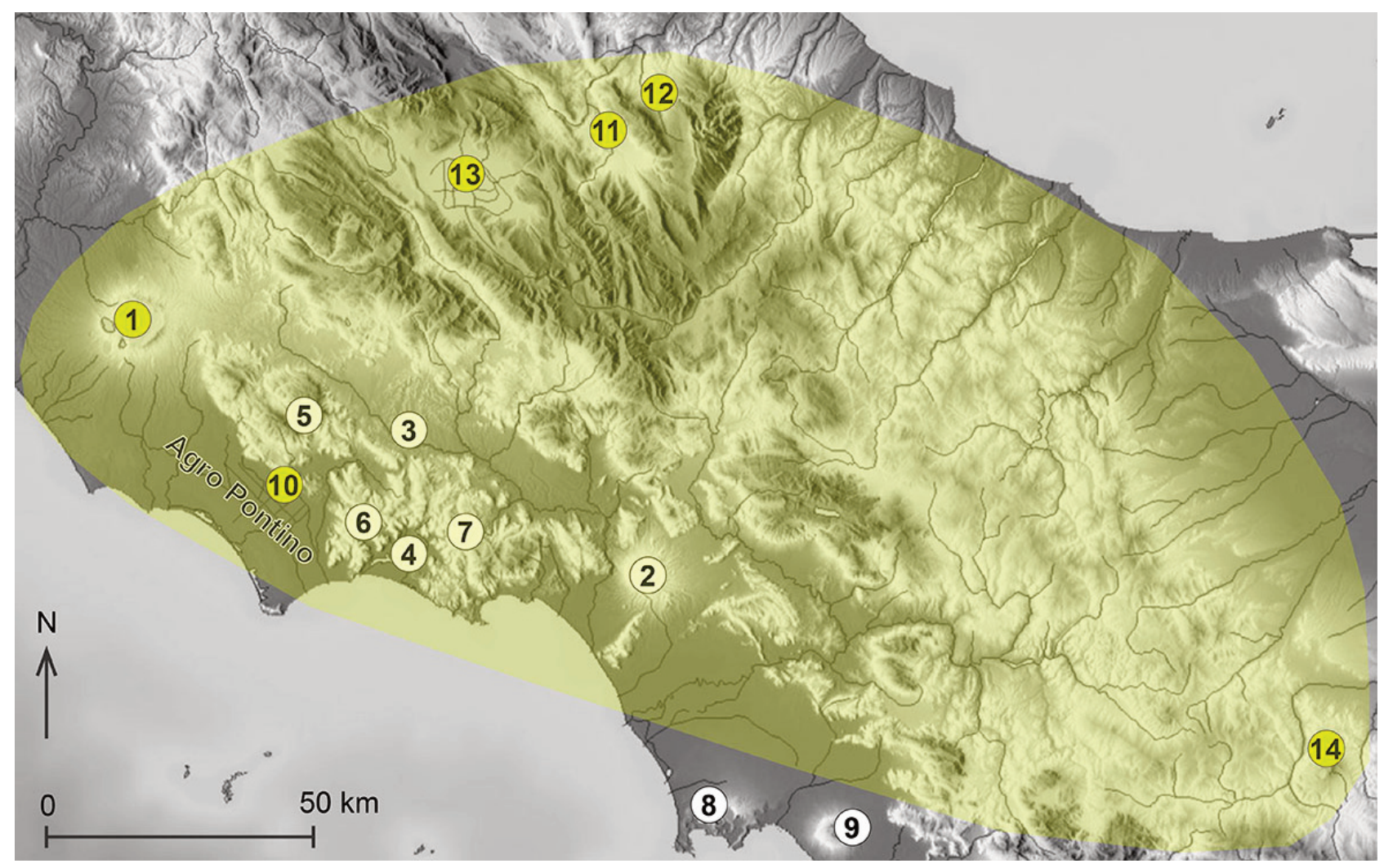

Figure 6. Inferred distribution of the Albano 5-7 tephra (DU 3-4): 1: Volcano Laziale; 10: Ricci; 11: Sulmona; 12; Tirino; 13: Fucino; 14: Laghi di Monticchio. For other numbers, reference is made to the legend of Figure1.

pering absolute dating.

After its deposition, the Albano 5-7 tephra was slightly reworked to accumulate in the lower, central part of the Borgo Ermada lagoonal plain in the interior Agro Pontino graben. At that time, backward incision of the paleoAmaseno and its tributaries, induced by the lowering of the sea level during the Last Glacial, had not yet reached the interior part of the graben and the lagoonal plain of the Borgo Ermada marine complex (MIS 5a) was still very level and non-dissected. Contemporary environmental conditions in this lower central part, with brackish to truly saline groundwater, may well have promoted the zeolitisation of the tephra and their concurrent lithification.

The ash layer found in the Cava Muracci at Cisterna di Latina, about $22 \mathrm{~km} \mathrm{NW}$ of the Ricci site and much closer to the Colli Albani, is a distal product of the earlier Albano 3 (DU2) eruptive stage, dated at $\sim 70$ kaBP [Gatta et al., 2017]. The strata covering this layer exhibit quite intense later soil formation and weathering [Gatta and Rolfo 2017], evidencing the differences in soil forming conditions that in Central Italy existed between the first and second half of the Würmian glacial period. The prominent differences in post-depositional soil formation and weathering between the Cava Muracci ash and the Ricci lithoid tuff are a major reason to exclude that the Ricci lithoid tuff is coeval with this Cava Mu- racci ash layer. A further argument is that, at Ricci, the time interval between the formation of the underlying lagoonal unit $(\sim 80 \mathrm{kaBP})$ and the Albano 3 eruptive stage ( $\sim 70 \mathrm{kaBP})$ is far too short $(\sim 10 \mathrm{ka})$ to allow for the development of the prominent Vertisol and associated petrocalcic horizon that we found underneath the tuff, thus providing strong evidence for a rather late Würmian age of the lithoid tuff.

The lithoid tuff at Ricci is the first recorded distal tephra deposit from this eruptive phase in southern Lazio (Figure 8). It demonstrates that under suited conditions Mid-Würmian tephra (40-36 kaBP) from the Albano Maar may be conserved in distal positions in the Tyrrhenian coastal basins, also testifying to the far wider distribution than earlier assumed [see e.g. Freda et al. 2006, Giraudi et al. 2011, Giaccio et al. 2013, Cross et al. 2014 and Giaccio et al. 2017b]. This tephra layer thus not only acts as an important tephrochronological marker for the inland basins of Central Italy, but may also act as such for its Tyrrhenian coastal basin.

Acknowledgements. The authors thank Ilenia Arienzo (Istituto Nazionale di Geofisica e Vulcanologia, Sezione di Napoli, Osservatorio Vesuviano, Naples, Italy) for her aid in the geochemical analyses. Jan van Arkel (IBED, University of Amsterdam, Amsterdam, The Netherlands) is acknowledged for his help with the illus- 
trations. Carmela Anastasia (independent archaeologist from Latina) was involved with and supported our study of the Ricci pit from the beginning on, focusing on the Bronze Age archaeology of that pit. We are also grateful for the very useful critical remarks comments and suggestions by two reviewers, which led to a considerable improvement of our manuscript. This research did not receive any specific grant from funding agencies in the public, commercial, or not-for-profit sectors.

\section{References}

Alonso-Zarza, A.M. and L.H. Tanner (2006). Paleoenvironmental record and applications of calcretes and palustrine carbonates (Vol. 416). Geological Society of America.

Arienzo, I., R. Moretti, L. Civetta, G. Orsi, and P. Papale (2010). The feeding system of Agnano-Monte Spina eruption (Campi Flegrei, Italy): dragging the past into present activity and future scenarios. Chemical Geology 270(1), 135-147.

Asioli, A., L. Capotondi, and M.B.C. Sironi (2005). The Tyrrhenian stage in the Mediterranean: definition, usage and recognition in the deep-sea record. A proposal. Rendiconti Lincei, 16(4), 297-310.

Bakels, C., J. Sevink, W. Kuijper and H. Kamermans (2015). The Agro Pontino region, refuge after the Early Bronze Age Avellino eruption of Mount Vesuvius, Italy? Analecta Preahistorica Leidensia 45. Leiden University. 55-68.

Balassone, G., F. Scordari, M. Lacalamita, E. Schingaro, A. Mormone, M. Piochi, C. Petti, and N. Mondillo (2013). Trioctahedral micas in xenolithic ejecta from recent volcanism of the Somma-Vesuvius (Italy): crystal chemistry and genetic inferences. Lithos 160161, 84-97, doi: 10.1016/j.lithos.2012.12.004.

Bosi, C., E. Locardi and I.M. Villa (1991). Il distretto magmatico abruzzese. Riassunti workshop "Evoluzione dei bacini Neogenici e loro rapporti con il magmatismo Plio-Quaternario nell'area ToscoLaziale”. Pisa 12-13 giugno 1991, 68-69.

Bronk Ramsey, C. (2013). OxCal 4.2 Web Interface Build (78).

Candy, I., S. Black and B.W. Sellwood (2004). Quantifying time scales of pedogenic calcrete formation using U-series disequilibria. Sedimentary Geology 170.3 20: 177-187.

Clark, P.U., A.S. Dyke, J.D. Shakun, A.E. Carlson, J. Clark, B. Wohlfarth, J.X. Mitrovica, S.W. Hostetler and A.M. McCabe (2009). The last glacial maximum. Science, 325m (5941), 710-714.

Cremaschi, M., N. Fedoroff, A. Guerreschi, J. Huxtable, N. Colombi, L. Castelletti and A. Maspero (1990). Sedimentary and pedological processes in the Upper
Pleistocene loess of northern Italy. The Bagaggera sequence. Quaternary International, 5, 23-38.

Cross, J.K., E.L. Tomlinson, G. Giordano, V.C. Smith, A.A. De Benedetti, J. Roberge, C. Manning, S. Wulf and M.A. Menzies (2014). High level triggers for explosive mafic volcanism: Albano Maar, Italy. Lithos 190-191, 137-153

D’Antonio, M., L. Civetta, G. Orsi, L. Pappalardo, M. Piochi, A. Carandente, S. de Vita, M.A. Di Vito and R. Isaia (1999). The present state of the magmatic system of the Campi Flegrei caldera based on a reconstruction of its behavior in the past $12 \mathrm{ka}$. Journal of Volcanology and Geothermal Research 91(2), 247-268.

De Astis, G., L. Pappalardo and M. Piochi (2004). Procida volcanic history: new insights into the evolution of the Phlegraean Volcanic District (Campania region, Italy). Bulletin of Volcanology 66(7), 622-641.

Deino, A.L., G. Orsi, S. de Vita and M. Piochi (2004). The age of the Neapolitan Yellow Tuff caldera-forming eruption (Campi Flegrei caldera - Italy) assessed by $40 \mathrm{Ar} / 39 \mathrm{Ar}$ dating method. Journal of Volcanology and Geothermal Research 133, 157-170.

De Vita, S., G. Orsi, L. Civetta, A. Carandente, M. D’Antonio, A. Deino, T. di Cesare, M.A. Di Vito, R.V. Fisher,R. Isaia, E. Marotta, A. Necco, M. Ort, L. Pappalardo, M., Piochi and J. Southon (1999). The Agnano-Monte Spina eruption (4100 years BP) in the restless Campi Flegrei caldera (Italy). Journal of Volcanology and Geothermal Research 91(2), 269-301.

De Vivo, B., G. Rolandi, P.B. Gans, A. Calvert, W.A. Bohrson, F.J. Spera and H.E. Belkin (2001). New constraints on the pyroclastic eruptive history of the Campanian volcanic Plain (Italy). Mineralogy and Petrology 73(1-3), 47-65.

Di Renzo, V., I. Arienzo, L. Civetta, M. D'Antonio, S. Tonarini, M.A. Di Vito and G. Orsi (2011). The magmatic feeding system of the Campi Flegrei caldera: architecture and temporal evolution. Chemical Geology 281 (3), 227-241.

Feiken, H. (2014) Dealing with biases: three geo-archaeological approaches to the hidden landscapes of Italy. Groningen Archaeological Studies 26, Barkhuis, Groningen, The Netherlands.

Follieri, M., M. Giardini, D. Magri and L. Sadori (1998). Palynostratigraphy of the last glacial period in the volcanic region of central Italy. Quaternary International 47, 3-20.

Freda, C., M. Gaeta, D.B. Karner, F. Marra, P.R. Renne, J. Taddeucci, P. Scarlato, J.N. Christensen and L. Dallai (2006). Eruptive history and petrologic evo- 
lution of the Albano multiple maar (Alban Hills, Central Italy). Bulletin of Volcanology 68, 567-591 Gatta, M., G. Sinopoli, M. Giardini, B. Giaccio, I. Hajdas, L. Pandolfi, G. Bailey, P. Spikins, M.F. Rolfo and L. Sadori (2016). Pollen from Late Pleistocene hyena (Crocuta crocuta spelaea) coprolites: An interdisciplinary approach from two Italian sites. Review of Palaeobotany and Palynology, 233, 56-66.

Gatta, M., B. Giaccio, F. Marra, M.F. Rolfo and B.R. Jicha (2017). Trace-element fingerprinting of the 69-36ka Colli Albani eruptive units: A preliminary dataset for archaeological and tephra studies in central-southern Italy. Journal of Archaeological Science: Reports, 16, 330-340.

Gatta, M. and M.F. Rolfo (2017). Cava Muracci: A New Middle-Upper Palaeolithic Site in West-Central Italy. Mediterranean Archaeology \& Archaeometry, 17(2).

Gaeta, M., C. Freda, J.N. Christensen, L. Dallai, F. Marra, D.B. Karner and P. Scarlato (2006). Time-dependent geochemistry of clinopyroxene from Alban Hills (Central Italy): clues to source and evolution of ultrapotassic magmas. Lithos 86, 330-346.

Gaeta, M., C. Freda, F. Marra, T. Di Rocco, F. Gozzi, I. Arienzo, B. Giaccio and P. Scarlato (2011). Petrology of the most recent ultrapotassic magmas from the Roman Province (Central Italy). Lithos, 127, 298-308.

Giaccio, B., A. Sposato, M. Gaeta, F. Marra, D.M. Palladino, J. Taddeucci, M. Barbieri, P. Messina and M.F. Rolfo (2007). Mid-distal occurrences of the Albano Maar pyroclastic deposits and their relevance for reassessing the eruptive scenarios of the most recent activity at the Colli Albani Volcanic District, Central Italy. Quaternary International, 171, 160-178.

Giaccio, B., I. Arienzo, G. Sottili, F. Castorina, M. Gaeta, S. Nomade, P. Galli and P. Messina (2013). Isotopic $(\mathrm{Sr}-\mathrm{Nd})$ and major element fingerprinting of distal tephras: an application to the Middle-Late Pleistocene markers from the Colli Albani volcano, central Italy. Quaternary Science Reviews 67, 190-206.

Giaccio, B., I. Hajdas, R. Isaia, A. Deino and S. Nomade (2017a). High-precision 14C and 40Ar/39Ar dating of the Campanian Ignimbrite (Y-5) reconciles the time-scales of climatic-cultural processes at $40 \mathrm{ka}$. Scientific Reports, 7.

Giaccio, B., E.M. Niespolo, A. Pereira, S. Nomade, P.R. Renne, P.G. Albert, I. Arienzo, E. Regattieri, B. Wagner, G., Zanchetta, M. Gaeta, P., P. Galli, G. Mannella E. Peronace, G. Sottili, F. Florindo, N. Leicher, F. Marra and E.L. Tomlinson (2017b). First integrated tephrochronological record for the last $\sim 190$ kyr from the Fucino Quaternary lacustrine succession, central Italy. Quaternary Science Reviews 158, 211-234.

Giraudi, C., G. Bodrato, M.R. Lucchi, N. Cipriani, I.M. Villa, B. Giaccio and G.M. Zuppi (2011). Middle and late Pleistocene glaciations in the Campo Felice Basin (central Apennines, Italy). Quaternary Research 75 (1), 219-230

Goldstein, S.L., P. Deines, E.H. Oelkers, R.L. Rudnick and L.M. Walter (2003). Standards for publication of isotope ratio and chemical data in Chemical Geology. Chemical Geology 202, 1-4.

Hearty, P.J. and G. Dai Pra (1986). Aminostratigraphy of Quaternary marine deposits in the Lazio region of central Italy. Zeitschrift fur Geomorphologie, Supplementband 62, 131-140.

Lambeck, K., F. Antonioli, A. Purcell and S. Silenzi (2004). Sea-level change along the Italian coast for the past 10,000 yr. Quaternary Science Reviews, 23(14), 1567-1598.

Lambeck, K., F. Antonioli, M. Anzidei, L. Ferranti, G. Leoni, G. Scicchitano and S. Silenzi (2011). Sea level change along the Italian coast during the Holocene and projections for the future. Quaternary International, 232(1), 250-257.

Langella, A., P. Cappelletti and R. de'Gennaro (2001). Zeolites in closed hydrologic systems. Reviews in mineralogy and geochemistry 45 (1), 235-260.

Mook, W.G. and H.J. Streurman (1983). Physical and chemical aspects of radiocarbon dating. Proceedings of the First International Symposium $14 \mathrm{C}$ and Archaeology, Groningen, 1981. Vol. 8. Council of Europe, 31-55.

Orsi, G., L. Civetta, M. D’Antonio, P. Di Girolamo and M. Piochi (1995). Step-filling and development of a three-layer magma chamber: the Neapolitan Yellow Tuff case history. Journal of Volcanology and Geothermal Research 67(4), 291-312.

Pabst, S., G. Wörner, L. Civetta and R. Tesoro (2008). Magma chamber evolution prior to the Campanian ignimbrite and Neapolitan Yellow Tuff eruptions (Campi Flegrei, Italy). Bulletin of Volcanology 70(8), 961-976.

Pappalardo, L., L. Civetta, M. D'Antonio, A. Deino, M. Di Vito, G. Orsi, A. Carandente, S. de Vita, R. Isaia and M. Piochi (1999). Chemical and Sr-isotopical evolution of the Phlegraean magmatic system before the Campanian Ignimbrite and the Neapolitan Yellow Tuff eruptions. Journal of Volcanology and Geothermal Research 91(2), 141-166.

Pappalardo, L., M. Piochi, M. D’Antonio, L. Civetta and R. Petrini (2002). Evidence for multi-stage magmatic evolution during the past $60 \mathrm{kyr}$ at Campi 
Flegrei (Italy) deduced from $\mathrm{Sr}, \mathrm{Nd}$ and $\mathrm{Pb}$ isotope data. Journal of Petrology 43 (8), 1415-1434.

Parlagreco, L., F. Mascioli, E. Miccadei, F. Antonioli, D. Gianolla, S. Devoti, G. Leoni and S. Silenzi (2011). New data on Holocene relative sea level along the Abruzzo coast (central Adriatic, Italy). Quaternary International, 232(1), 179-186.

Pillans, B., J. Chappell and T.R. Naish (1998). A review of the Milankovitch climatic beat: template for Plio-Pleistocene sea-level changes and sequence stratigraphy. Sedimentary Geology 122 (1), 5-21.

Piochi, M., L. Civetta and G. Orsi (1999). Mingling in the magmatic system of Ischia (Italy in the past 5 Ka. Mineralogy and Petrology 66(4), 227-258.

Piochi, M., L. Pappalardo and G. De Astis (2004). Geochemical and Isotopical variation whitin the Campanian Comagmatic province: implications on magma source composition. Annals of Geophysics 47, (4), 1485-1499, ISSN: 1593-5213.

Piochi, M., C.R.J. Kilburn, M.A. Di Vito, A. Mormone, A. Tramelli, C. Troise and G. De Natale (2014). The volcanic and geothermally active Campi Flegrei caldera: an integrated multidisciplinary image of its buried structure. International Journal of Earth Science 103, (2), 401-421, doi:10.1007/s00531-0130972-7.

Reimer, P.J., E. Bard, A. Bayliss, J.W. Beck, P.G. Blackwell, C.B. Ramsey, C.E. Buck, H. Cheng, R.L. Edwards, M. Friedrich, P.M. Grootes, T.P. Guilderson, H. Haflidason, I. Hajdas, C. Hatté, T.J. Heaton, D.L. Hoffmann, A.G. Hogg, K.A. Hughen, K.F. Kaiser, B. Kromer, S.W. Manning, M.,Niu, R.W. Reimer, D.A. Richards, E.M. Scott, J.R. Southon, R.A. Staff, C.S.M. Turney and J. Van der Plicht (2013). IntCal13 and Marine13 radiocarbon age calibration curves 0-50,000 years cal BP. Radiocarbon 55 (4), 1869-1887.

Schellmann, G., U. Radtke, E.K. Potter, T.M. Esat and M.T. McCulloch (2004). Comparison of ESR and TIMS U/Th dating of marine isotope stage (MIS) $5 \mathrm{e}, 5 \mathrm{c}$, and $5 \mathrm{a}$ coral from Barbados-implications for palaeo sea-level changes in the Caribbean. Quaternary International 120 (1), 41-50.

Sevink, J., A. Remmelzwaal and O.C. Spaargaren (1984). The soils of Southern Lazio and adjacent Campania. Publ. Fys. Geogr. Lab. UvA nr. 38, University of Amsterdam, Amsterdam, The Netherlands.

Sevink, J., M.J. van Bergen, J. van der Plicht, H. Feiken, C. Anastasia and A. Huizinga (2011). Robust date for the Bronze Age Avellino eruption (SommaVesuvius): $3945+/-10$ calBP $(1995+/-10$ calBC).
Quaternary Science Reviews 30(9-10), 1035-1046.

Sevink J., J. van der Plicht, H. Feiken, P.M. van Leusen and C.C. Bakels (2013). The Holocene of the Agro Pontino graben: Recent advances in its palaeogeography, palaeoecology, and tephrostratigraphy. Quaternary International 303, 153-162.

Van Gorp, W. and J. Sevink (2018). Distal deposits of the Avellino eruption as a marker for the detailed reconstruction of the Early Bronze Age depositional environment in the Agro Pontino and Fondi Basin (Lazio, Italy). Special Issue of Quaternary International, 2018. In press.

Vezzoli, L. (1988). Island of Ischia. Consiglio Nazionale delle Ricerche. Italy.

Wright, V.P. (1990). Estimating rates of calcrete formation and sediment accretion in ancient alluvial deposits. Geological Magazine 127(03), 273-276.

Zucca, C., S. Andreucci, İ. Akşit, Y.K. Koca, S. Madrau, V. Pascucci, F. Previtali, S.M. Shaddad and S. Kapur (2014). Buried palaeosols of NW Sardinia (Italy) as archives of the Late Quaternary climatic fluctuations. Catena, 122, 72-90.

\footnotetext{
*Corresponding author: Jan Sevink, Institute for Biodiversity and Ecosystem Dynamics (IBED), University of Amsterdam, Amsterdam, The Netherlands; email: j.sevink@uva.nl.
}

C 2018 by the Istituto Nazionale di Geofisica e Vulcanologia. All rights reserved. 